\title{
Evaluation of Multiplex Polymerase Chain Reaction Assay for the Simultaneous Detection of Sexually Transmitted Infections Using Swab Specimen
}

\author{
Sun-Hwa Park ${ }^{1,2}$, Kyung-Ah Hwang ${ }^{2}$, Ji Hoon Ahn², Jae-Hwan Nam ${ }^{1 *}$ \\ 'Department of Biotechnology, The Catholic University of Korea, 43-1 Yeokgok 2-dong, Wonmi-gu, Bucheon, \\ Gyeonggi-do, 420-743, Korea \\ ${ }^{2}$ Department of Research and Development, Genetree Research, Seoul, Korea
}

\section{Corresponding}

Jae-Hwan Nam, PhD.

Department of Biotechnology,

The Catholic University of Korea, 43-1

Yeokgok 2-dong, Wonmi-gu, Bucheon,

Gyeonggi-do 14662, Republic of Korea

Phone : +82-2-2164-4917

Fax : +82-2-2164-4917

E-mail : jhnam@catholic.ac.kr

Received : November 28, 2019

Revised : February 19, 2020

Accepted : February 21, 2020

No potential conflict of interest relevant to this article was reported.

Copyright (C) 2020 Journal of Bacteriology and Virology

(c) This is an Open Access article distributed under the terms of the Creative Commons Attribution Non-Commercial License (http://creativecommons.org/

license/by-nc/3.0/)
Sexually transmitted infections (STIS) are caused by the spread of pathogens via sexual activity and can cause serious complications if left untreated, regardless of their symptoms. Therefore, early diagnosis of STI is important, and molecular diagnostic methods for rapid detection and monitoring are needed. In this study, we evaluated a multiplex polymerase chain reaction (PCR) kit for simultaneously detecting 13 different bacterial, fungal, and viral microorganisms that cause STIs. The kit performance was evaluated for its sensitivity, lot-to-lot variation, and interference in detecting different pathogens. Additionally, its clinical usefulness was evaluated by estimating its sensitivity and specificity for clinical samples. The limit of detection (LOD) was 0.021-50.104 copies for each pathogen. In the tests of lot-to-lot, $100 \%$ of positive samples were detected at low concentrations and negative samples all showed negative results. This result confirms that there is no the variation of lot-to-lot. In the test for interference between pathogens, the efficiency of amplification for each pathogen was not significantly reduced and no nonspecific amplification product was formed. We tested 322 vaginal swab samples using the multiplex PCR kit and confirmed that its clinical sensitivity and specificity were $100 \%$ for all pathogens. This multiplex PCR kit can be used widely for rapid diagnosis and monitoring of STIs.

Key Words: sexually transmitted infection, multiplex PCR, evaluation

\section{INTRODUCTION}

Sexually transmitted infections (STIS), also known as sexually transmitted diseases (STDs) or venereal diseases, are spread by sexual activity (1). They are one of the most common types of infectious disease and can be caused by bacteria, fungi, viruses, and parasites. Causes of STIs include the bacteria Chlamydia trachomatis (CT), Gardnerella vaginalis (GV), Haemophilus ducreyı $(\mathrm{HD})$, Mycoplasma genitalium (MG), Mycoplasma hominis (MH), Neisseria gonorrhoeae (NG), Treponema pallidum (TP), Ureaplasma parvum (UP) and Ureaplasma urealyticum (UU), the fungus Candida albicans (CA) (2-8), the viruses herpes simplex-1 (HSV-1) and herpes simplex-2 (HSV-2), and the parasite Trichomonas vaginalis (TV) $(6,8-10)$. 
The World Health Organization estimates that one million new STIs occur per day. In Korea, 24,526 cases of STI were reported in 2016, including 8,438 cases of CT infection, 3,615 cases of NG infection, and 1,569 cases of TP infection, which is an increase of $32.9 \%$ compared to the number in $2015(11,12)$. These diseases are rarely cured without treatment. Although $70-80 \%$ of STIs are asymptomatic, they can be dangerous. However, most STIs are easy to treat if they are diagnosed early (12).

The pathogens that cause these STIs are very diverse and often cause complex infections. Although microbial culture is typically performed to identify the pathogens, this technique can take a long time and each pathogen requires complex and different incubation conditions (11). Contamination can also occur during culture (12). By comparison, molecular diagnostics using polymerase chain reaction (PCR), which tests directly for the presence of microorganism DNA, can give results for single or multiple infections within a short time. This technique is now widely used in diagnostic laboratories. Additionally, the use of multiplex PCR, which can detect multiple target DNAs, is increasing $(13,14)$.

In this study, we evaluated the analytical and clinical usefulness of a commercially available multiplex PCR kit for detecting 13 different microorganisms that can cause STIs without the need for culture. Analytic performance was validated by measuring sensitivity, lot-to-lot variation, and competitive interference. Sensitivity was determined by serially diluting the DNA standards of 13 pathogens before performing PCR. The kit identified the lowest amount of the analyte with a $95 \%$ positivity rate. The variation of lot-to-lot was verified using three different lots of the same reagents, and all were detected within the range of concentrations prepared by diluting the reference material. We also confirmed the lack of interference between pathogens with a high prevalence of coinfection. The clinical performance of the kit was then evaluated using clinical samples. Seven pathogens that were not included in control kit were used as a control and were detected by sequencing.

\section{MATERIALS AND METHODS}

\section{Clinical samples}

From July to September 2016, swab specimens were collected from 322 patients suspected as having an STI. These samples were collected by Genetree Research, Inc. from local hospitals. DNA was purified from all swab specimens and deidentified samples were transferred to The Catholic University of Korea. Swab specimens were stored at $4^{\circ} \mathrm{C}$ prior to analysis. All specimens were tested with the $\mathrm{E}$ kit and several samples were subjected to sequencing. The study was approved by the Institutional Review Board Committee for Ethics and Research of the Catholic University of Korea (1040395-201809-17)

\section{DNA extraction methods}

The swab specimens in the collection tubes were equilibrated to room temperature and mixed by vortexing. The caps from the specimen tubes were removed carefully to avoid contamination and $1-\mathrm{mL}$ specimens were transferred into 1.5-mL microtubes and centrifuged at 1,500xg for $15 \mathrm{~min}$, after which the supernatant was discarded. We then resuspended the pellet in $1 \mathrm{~mL}$ of phosphate-buffered saline by vortexing. DNA was extracted from the pretreated specimens using the QIAamp DNA mini kit (Qiagen, Hilden, Germany) in accordance with the manufacturer's instructions. Total DNA was stored at $-80^{\circ} \mathrm{C}$ until analysis. The quality of extracted DNA was measured with a spectrophotometer (BioTek, Winooski, VT, USA) to confirm DNA purity and yield. 


\section{Multiplex PCR assay}

We evaluated the E kit (Genetree Research, Seoul, Korea) using a 2720 Thermal Cycler (Applied Biosystems, Foster City, CA, USA). Multiplex PCR distinguishes pathogens based on the sizes of the amplified bands. The kit contains Primer Set 1 , which can detect TV, UU, MH, MG, NG, and CT pathogens, and Primer Set 2, which can detect HD, HSV-2, GV, HSV-1, TP, CA, and UP pathogens. The target genes amplified from the 13 pathogens are listed in Table 1. The kit also includes internal controls to confirm that clinical specimens are successfully amplified and detected through electrophoresis analysis (820 base pairs). Internal control used B-actin in the human gene. As a negative control, distilled water was used rather than DNA as the PCR template. To verify the integrity of the primers used in the PCR assay, positive DNA controls from the kit were evaluated in the presence of all primer pairs.

Table 1. Pathogen-specific regions amplified

\begin{tabular}{|c|c|c|c|}
\hline $\begin{array}{l}\text { Organism } \\
\text { (Accession) }\end{array}$ & Target Gene & Amplicon Size (bp) & position \\
\hline $\begin{array}{c}\text { CA } \\
\text { (MN743895) }\end{array}$ & internal transcribed spacer & 187 & $40-226$ \\
\hline $\begin{array}{c}\mathrm{CT} \\
\text { (MG733347) }\end{array}$ & major outer membrane protein & 117 & $5-121$ \\
\hline $\begin{array}{c}\text { GV } \\
(J Q 354967)\end{array}$ & CPN60 & 407 & $4-410$ \\
\hline $\begin{array}{c}\text { HD } \\
\text { (AY603047) } \\
\text { HSV-1 }\end{array}$ & hemoglobin receptor precursor & 670 & $1685-2354$ \\
\hline (EF177455) & glycoprotein B (UL27) & 330 & $1279-1608$ \\
\hline $\begin{array}{c}\text { HSV-2 } \\
\text { (KF588415) }\end{array}$ & glycoprotein B (UL27) & 570 & $1042-1611$ \\
\hline $\begin{array}{c}\text { MG } \\
(\text { KP318824) }\end{array}$ & adhesion (mgpB) & 248 & $231-478$ \\
\hline $\begin{array}{c}\text { MH } \\
\text { (KU726667) }\end{array}$ & $16 \mathrm{~S}$ rRNA & 335 & $91-425$ \\
\hline $\begin{array}{c}\text { NG } \\
(\mathrm{AJ} 010733)\end{array}$ & porA pseudogene & 175 & $657-731$ \\
\hline TP (M88769) & 47-kilodalton antigen gene & 252 & $561-812$ \\
\hline TV (L23861) & G7 hypothetical protein & 690 & $349-1038$ \\
\hline UP (AF085733) & UreB & 119 & $632-750$ \\
\hline $\begin{array}{c}\text { UU } \\
\text { (AF085721) }\end{array}$ & UreA & 431 & $302-732$ \\
\hline
\end{tabular}

Abbreviations: CA, Candida albicans; CT, Chlamydia trachomatis; GV, Gardnerella vaginalis; HD, Haemophilus ducreyi, HSV-1, Herpes simplex 1; HSV-2, Herpes simplex 2; MG, Mycoplasma genitalium; MH, Mycoplasma hominis; NG, Neisseria gonorrhoeae; TP, Treponema pallidum; TV, Trichomonas vaginalis; UP, Ureaplasma parvum; UU, Ureaplasma urealyticum.

PCR amplification was performed as described in the kit manual. The PCR conditions were as follows: 5 min at $50^{\circ} \mathrm{C}$ and 10 min at $94^{\circ} \mathrm{C}$, followed by 40 cycles of denaturation at $94^{\circ} \mathrm{C}$ for $20 \mathrm{~s}$, annealing at $62^{\circ} \mathrm{C}$ for 1 min $20 \mathrm{~s}$, and extension at $72^{\circ} \mathrm{C}$ for $1 \mathrm{~min}$, and a final extension at $72^{\circ} \mathrm{C}$ for $5 \mathrm{~min}$. The amplified PCR products were electrophoresed in $2.2 \%(\mathrm{w} / \mathrm{v})$ agarose gels and stained with ethidium bromide. The band size of each amplification product was checked against the marker DNA (positive DNA) supplied with the kit (Fig. 1) 


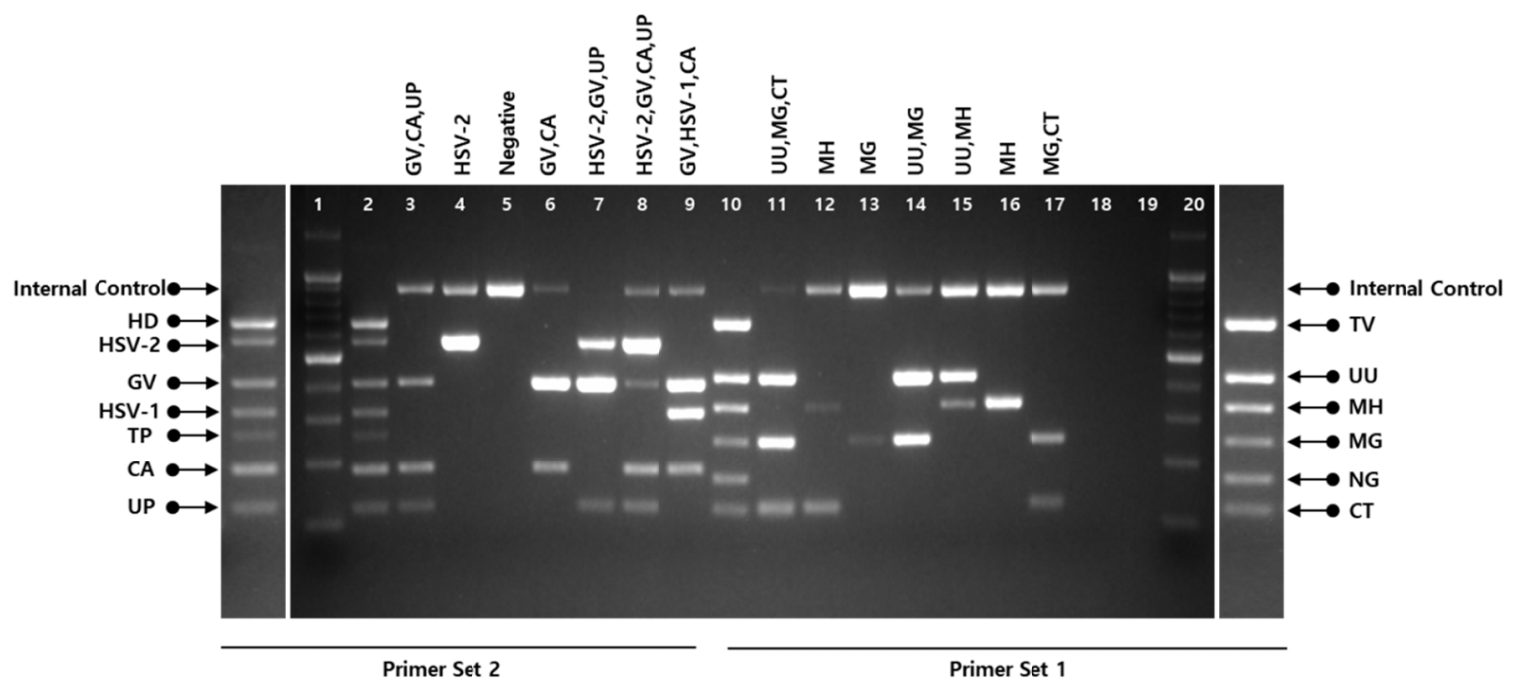

Fig. 1. DNA amplification by multiplex PCR (E kit) in clinical specimens

The band size of each amplification product was checked against the positive control. Lanes \#1 and 20: Ladder to distinguish amplification bands. Lane \#2: positive control for 7 pathogens amplified by Primer Set 2, Lane \#10: positive control for 6 pathogens amplified by Primer Set 1, Lanes \#3-9 and \#11-17: PCR results from clinical samples, Lanes \#18 and 19: negative control (distilled water).

Abbreviations: HD, Haemophilus ducreyi; HSV-2, Herpes simplex 2; GV, Gardnerella vaginalis" HSV-1, Herpes simplex 1; TP, Treponema pallidum; CA, Candida albicans; UP, Ureaplasma parvum; TV, Trichomonas vaginalis; UU, Ureaplasma urealyticum; MH, Mycoplasma hominis; MG, Mycoplasma genitalium; NG, Neisseria gonorrhoeae; CT, Chlamydia trachomatis.

\section{Wise STD 6 detection Kit}

The Wise STD 6 detection kit (Wisemeditec, Anyang, Korea) as control consists only of Primer Set 1 (unrevealed), which can detect TV, UU, MH, MG, NG and CT pathogens. Amplification reactions were performed in a volume of $16 \mu \mathrm{L}$ consisting of $8 \mu \mathrm{L}$ STD6 mixture, $2 \mu \mathrm{L}$ of primer mix, $2 \mu \mathrm{L}$ of Internal control primer mix, $4 \mu \mathrm{L}$ of DNA template. The PCR conditions were as follows: $5 \mathrm{~min}$ at $50^{\circ} \mathrm{C}$ and $10 \mathrm{~min}$ at $94^{\circ} \mathrm{C}$, followed by 40 cycles of denaturation at $94^{\circ} \mathrm{C}$ for $20 \mathrm{~s}$, annealing at $62^{\circ} \mathrm{C}$ for $1 \mathrm{~min} 20 \mathrm{~s}$, and extension at $72^{\circ} \mathrm{C}$ for $1 \mathrm{~min}$, and a final extension at $72{ }^{\circ} \mathrm{C}$ for $5 \mathrm{~min}$. The amplified PCR products were electrophoresed in $2.2 \%(\mathrm{w} / \mathrm{v})$ agarose gels and stained with ethidium bromide.

\section{Sequencing}

Amplicons were purified using an exonuclease/shrimp alkaline phosphatase mixture and sequenced using $A B I$ Prism BigDye Terminator version 3.1 (Applied Biosystems) with both forward and reverse sequence-specific primers. Twenty nanograms of purified PCR products were used in a $10-\mu \mathrm{L}$ sequencing reaction solution containing $1 \mu \mathrm{L}$ of BigDye Terminator v3.1 and $0.1 \mu \mathrm{M}$ of the same PCR primer. Sequencing reactions were performed as follows: 25 cycles of $10 \mathrm{~s}$ at $96^{\circ} \mathrm{C}, 5 \mathrm{~s}$ at $50^{\circ} \mathrm{C}$, and $4 \mathrm{~min}$ at $60^{\circ} \mathrm{C}$. Sequence data were generated using the ABI Prism 3730 DNA Analyzer (Applied Biosystems). Sequences were analyzed using the Basic local alignment search tool (BLAST) from The National Center for Biotechnology Information.

\section{Statistical analyses}

The limit of detection (LOD) was calculated using 95\% probit analysis and IBS SPSS Statistics (v. 20; SPSS, Inc., Chicago, IL, USA), and clinical data were calculated using MedCalc software version 14.8.1 (MedCalc softwvare, Ostend, Belgium). 


\section{RESULTS}

\section{Determination of sensitivity}

To verify the sensitivity of the E kit, we performed sensitivity testing using 24 replicates with four concentrations of kit standards at 0.01-1,000 copies per pathogen. Viral DNA (Vircell S.L., Granada, Spain) or cloned compounds were used in a tenth serial dilutions with TE buffer to determine sensitivity. See Table 2 for diluent concentrations for each pathogen. The sensitivities determined from the $95 \%$ confidence level in the probit analysis using repeated measures data were 0.021-50.104 copies for each pathogen. The sensitivities of the E kit were estimated as 1.212 copies for CT, 1.708 copies for NG, 4.3 copies for MG, 2.636 copies for MH, 33.577 copies for UU, 0.021 copies for TV, 3.071 copies for UP, 4.918 copies for CA, 2.636 copies for TP, 17.077 copies for HSV-1, 4.918 copies for GV, 16.231 copies for HSV-2, and 50.104 copies for HD (Table 2).

Table 2. Limit of detection of E kit multiplex PCR

\begin{tabular}{|c|c|c|}
\hline Pathogen & $\begin{array}{l}\text { DNA Concentrations } \\
(\text { copies } / \mu \mathrm{L})\end{array}$ & LOD \\
\hline$C A$ & $0.01-10$ & 4.918 \\
\hline $\mathrm{CT}$ & $0.01-10$ & 1.212 \\
\hline GV & $0.01-10$ & 4.918 \\
\hline$H D$ & $1-1000$ & 50.104 \\
\hline HSV-1 & $0.1-100$ & 17.077 \\
\hline HSV-2 & $0.1-100$ & 16.231 \\
\hline MG & $0.1-100$ & 4.3 \\
\hline $\mathrm{MH}$ & $0.1-100$ & 2.636 \\
\hline NG & $0.01-10$ & 1.708 \\
\hline TP & $0.1-100$ & 2.636 \\
\hline $\mathrm{TV}$ & $0.001-1$ & 0.021 \\
\hline UP & $0.1-100$ & 3.071 \\
\hline UU & $0.1-100$ & 33.577 \\
\hline
\end{tabular}

Abbreviations: LOD, limit of detection. 


\section{Determination of lot-to-lot variation}

Three different lots of the same reagent showed a $100 \%$ detection rate for both medium $(1,000 \times$ LOD $)$ and low (10 $\times$ LOD) concentration reference materials over 20 iterations (Table 3). No visible changes in band strength were observed. All negative samples (distilled water) produced negative results. These results confirm the within-run, between-run, and lot variation of the assay for all positive samples.

Table 3. Lot-to-lot variation for each pathogen

\begin{tabular}{|c|c|c|c|c|}
\hline \multirow{2}{*}{ Pathogen } & \multirow{2}{*}{ Concentration } & \multicolumn{3}{|c|}{ No. of Positive reaction } \\
\hline & & Lot 1 & Lot 2 & Lot 3 \\
\hline \multirow{2}{*}{ CA } & $10 \times \mathrm{LOD}$ & 20 & 20 & 20 \\
\hline & $1000 \times$ LOD & 20 & 20 & 20 \\
\hline \multirow{2}{*}{$\mathrm{CT}$} & $10 \times$ LOD & 20 & 20 & 20 \\
\hline & $1000 \times$ LOD & 20 & 20 & 20 \\
\hline \multirow{2}{*}{ GV } & $10 \times \mathrm{LOD}$ & 20 & 20 & 20 \\
\hline & $1000 \times$ LOD & 20 & 20 & 20 \\
\hline \multirow{2}{*}{ HD } & $10 \times \operatorname{LOD}$ & 20 & 20 & 20 \\
\hline & $1000 \times$ LOD & 20 & 20 & 20 \\
\hline \multirow{2}{*}{ HSV-1 } & $10 \times \mathrm{LOD}$ & 20 & 20 & 20 \\
\hline & $1000 \times$ LOD & 20 & 20 & 20 \\
\hline \multirow{2}{*}{ HSV-2 } & $10 \times \mathrm{LOD}$ & 20 & 20 & 20 \\
\hline & $1000 \times$ LOD & 20 & 20 & 20 \\
\hline \multirow{2}{*}{ MG } & $10 \times \mathrm{LOD}$ & 20 & 20 & 20 \\
\hline & $1000 \times$ LOD & 20 & 20 & 20 \\
\hline \multirow{2}{*}{$\mathrm{MH}$} & $10 \times \operatorname{LOD}$ & 20 & 20 & 20 \\
\hline & $1000 \times$ LOD & 20 & 20 & 20 \\
\hline \multirow{2}{*}{ NG } & $10 \times \operatorname{LOD}$ & 20 & 20 & 20 \\
\hline & $1000 \times$ LOD & 20 & 20 & 20 \\
\hline \multirow{2}{*}{ TP } & $10 \times$ LOD & 20 & 20 & 20 \\
\hline & $1000 \times$ LOD & 20 & 20 & 20 \\
\hline \multirow{2}{*}{ TV } & $10 \times \mathrm{LOD}$ & 20 & 20 & 20 \\
\hline & $1000 \times$ LOD & 20 & 20 & 20 \\
\hline \multirow{2}{*}{ UP } & $10 \times \mathrm{LOD}$ & 20 & 20 & 20 \\
\hline & $1000 \times$ LOD & 20 & 20 & 20 \\
\hline \multirow{2}{*}{ UU } & $10 \times \mathrm{LOD}$ & 20 & 20 & 20 \\
\hline & $1000 \times$ LOD & 20 & 20 & 20 \\
\hline
\end{tabular}

0 


\section{Determination of interference}

The interference test was conducted for cases of NG and CT co-infections as well as cases of HSV-1 and HSV-2 co-infections. The competition interference test was conducted by defining each concentration as $10 \times$ LOD, 100 $\times$ LOD, and $1,000 \times$ LOD. The interference assays confirmed that the pathogens could be detected at all concentrations without a loss in sensitivity (Table 4).

Table 4. Test for interference between CT and NG, HSV-1 and HSV-2

\begin{tabular}{|c|c|c|c|}
\hline $\begin{array}{c}\begin{array}{c}\text { Bacterial species } \\
\text { (concentration) }\end{array} \\
\end{array}$ & $\begin{array}{c}\text { NG } \\
(10 \times \text { LOD })\end{array}$ & $\begin{array}{c}\mathrm{NG} \\
(100 \times \text { LOD }) \\
\end{array}$ & $\begin{array}{c}\text { NG } \\
(1000 \times \text { LOD }) \\
\end{array}$ \\
\hline \multirow{2}{*}{$\begin{array}{c}\mathrm{CT} \\
(10 \times \mathrm{LOD})\end{array}$} & NG-positive & NG-positive & NG-positive \\
\hline & CT-positive & CT-positive & $\begin{array}{l}\text { CT-weakly } \\
\text { positive }\end{array}$ \\
\hline \multirow{2}{*}{$\begin{array}{c}C T \\
(100 \times \text { LOD })\end{array}$} & NG-positive & NG-positive & NG-positive \\
\hline & CT-positive & CT-positive & CT-positive \\
\hline \multirow{2}{*}{$\begin{array}{c}\mathrm{CT} \\
(1000 \times \text { LOD })\end{array}$} & $\begin{array}{l}\text { NG-weakly } \\
\text { positive }\end{array}$ & NG-positive & NG-positive \\
\hline & CT-positive & CT-positive & CT-positive \\
\hline $\begin{array}{c}\text { virus species } \\
\text { (concentration) }\end{array}$ & $\begin{array}{c}\text { HSV-1 } \\
(10 \times \text { LOD }) \\
\end{array}$ & $\begin{array}{c}\text { HSV-1 } \\
(100 \times \text { LOD }) \\
\end{array}$ & $\begin{array}{c}\text { HSV-1 } \\
(1000 \times \text { LOD })\end{array}$ \\
\hline \multirow[t]{2}{*}{$\begin{array}{c}\text { HSV-2 } \\
(10 \times \text { LOD })\end{array}$} & HSV-1-positive & HSV-1-positive & HSV-1-positive \\
\hline & HSV-2-positive & HSV-2-positive & HSV-2-positive \\
\hline \multirow[t]{2}{*}{$\begin{array}{c}\text { HSV-2 } \\
(100 \times \text { LOD })\end{array}$} & HSV-1-positive & HSV-1-positive & HSV-1-positive \\
\hline & HSV-2-positive & HSV-2-positive & HSV-2-positive \\
\hline \multirow[t]{2}{*}{$\begin{array}{c}\text { HSV-2 } \\
(1000 \times \text { LOD })\end{array}$} & HSV-1-positive & HSV-1-positive & HSV-1-positive \\
\hline & HSV-2-positive & HSV-2-positive & HSV-2-positive \\
\hline
\end{tabular}

\section{Evaluation of the method using clinical samples}

We used 322 human vaginal swab samples to evaluate the accuracy of the $E$ kit (test) compared to the Wise STD 6 detection kit (control). As described above, the $\mathrm{E}$ kit can detect 13 pathogens (TV, UU, MH, MG, NG, CT, HD, HSV-2, GV , HSV-1, TP, CA, and UP), whereas the Wise STD 6 detection kit can detect 6 pathogens (NG, CT, TV, MG, MH, and UU). Therefore, the presence of the 7 microorganisms (HSV-1, HSV-2, GV, TP, CA, HD, and UP) detected by the E kit but not by the Wise STD 6 detection kit was confirmed by sequencing. Additionally, if the results of the two kits were discordant, sequencing was conducted to verify the clinical sensitivity and specificity. All results from the E kit showed that clinical sensitivity and specificity were 100\% (Table 5). However, 4 samples showed different results in PCR with the Wise STD 6 kit as control kit and $\mathrm{E}$ kit as experimental kit. These results were confirmed by sequencing. The BLAST match rate was consistently $>90 \%$. 
Table 5. Sensitivities and specificities of E kit in 322 swab specimens

\begin{tabular}{|c|c|c|c|c|c|c|}
\hline \multirow{2}{*}{$\begin{array}{c}\text { Control PCR } \\
\text { \& sequencing } \\
\text { Organism }\end{array}$} & \multicolumn{2}{|c|}{ Results } & \multirow{2}{*}{$\begin{array}{c}\text { Sensitivity (\%) } \\
(95 \% \mathrm{Cl})\end{array}$} & \multirow{2}{*}{$\begin{array}{l}\text { Specificity (\%) } \\
\quad(95 \% \mathrm{Cl})\end{array}$} & \multirow{2}{*}{$\begin{array}{l}\text { PPV } \\
(\%)\end{array}$} & \multirow{2}{*}{$\begin{array}{l}\text { NPV } \\
(\%)\end{array}$} \\
\hline & Positive & Negative & & & & \\
\hline$C A$ & 44 & 278 & $\begin{array}{c}100 \\
(96.61-100)\end{array}$ & $\begin{array}{c}100 \\
(99.36-100)\end{array}$ & 100 & 100 \\
\hline $\mathrm{CT}$ & 38 & 284 & $\begin{array}{c}100.0 \\
(95.01-100)\end{array}$ & $\begin{array}{c}100.0 \\
(99.39-100)\end{array}$ & 100 & 100 \\
\hline GV & 138 & 184 & $\begin{array}{c}100 \\
(98.87-100)\end{array}$ & $\begin{array}{c}100 \\
(99.00-100)\end{array}$ & 100 & 100 \\
\hline$H D$ & 0 & 322 & NA & NA & 100 & 100 \\
\hline HSV-1 & 17 & 305 & $\begin{array}{c}100 \\
(94.31-100)\end{array}$ & $\begin{array}{c}100 \\
(99.40-100)\end{array}$ & 100 & 100 \\
\hline HSV-2 & 24 & 298 & $\begin{array}{c}100 \\
(94.22-100)\end{array}$ & $\begin{array}{c}100 \\
(99.40-100)\end{array}$ & 100 & 100 \\
\hline $\mathrm{MH}$ & 65 & 257 & $\begin{array}{c}100 \\
(97.75-100)\end{array}$ & $\begin{array}{c}100 \\
(99.29-100)\end{array}$ & 100 & 100 \\
\hline MG & 33 & 289 & $\begin{array}{c}100 \\
(94.72-100)\end{array}$ & $\begin{array}{c}100 \\
(99.40-100)\end{array}$ & 100 & 100 \\
\hline NG & 28 & 294 & $\begin{array}{c}100.0 \\
(94.40-100)\end{array}$ & $\begin{array}{c}100.0 \\
(99.40-100)\end{array}$ & 100 & 100 \\
\hline $\mathrm{TP}$ & 1 & 321 & $\begin{array}{c}100 \\
(93.02-100)\end{array}$ & $\begin{array}{c}100 \\
(99.41-100)\end{array}$ & 100 & 100 \\
\hline TV & 16 & 306 & $\begin{array}{c}100 \\
(94.22-100)\end{array}$ & $\begin{array}{c}100 \\
(99.40-100)\end{array}$ & 100 & 100 \\
\hline UP & 74 & 248 & $\begin{array}{c}100 \\
(98.68-100)\end{array}$ & $\begin{array}{c}100 \\
(99.09-100)\end{array}$ & 100 & 100 \\
\hline UU & 60 & 262 & $\begin{array}{c}100 \\
(96.79-100)\end{array}$ & $\begin{array}{c}100 \\
(99.35-100)\end{array}$ & 100 & 100 \\
\hline
\end{tabular}

Abbreviations: PCR, polymerase chain reaction; $\mathrm{Cl}$, confidence interval; PPV, positive predictive value; NPV, negative predictive value.

\section{DISCUSSION}

The standard methods for diagnosing STIs are culture and serologic tests. However, for TP, samples showing positive results following culture were reported as negative in serologic testing, and antibody detection was found to be less sensitive than the culture method $(15,16)$. Although the most appropriate test for viruses such as HSV-2 is cell culture, this assay shows low sensitivity (17). HD is also difficult to cultivate experimentally $(18,19)$. PCR methods that are rapid and highly sensitive are used when low-sensitivity test methods and culture are not possible $(20,21)$. Therefore, PCR can improve the ability to diagnose infectious diseases $(16,20-22,23)$. It has been suggested that diagnosis methods involving amplification of nucleic acid are $20-30 \%$ more sensitive than other methods $(24,25)$. Additionally, multiplex PCR allows for the rapid identification of several pathogens in the same specimen. Because STIs have a high incidence of 
coinfections, multiplex PCR rather than single PCR is suitable for their diagnosis and treatment: its ability to detect multiple pathogens simultaneously is a major advantage $(13,14)$. Therefore, several multiplex diagnostic kits have been developed for detecting STI pathogens.

In this study, we evaluated the E kit, which can detect 13 STI pathogens simultaneously. The usefulness of molecular diagnostics is often evaluated by analytical evaluation and clinical performance testing. The analytical and clinical performance for $\mathrm{E}$ kit were assessed to determine whether it is appropriate for STI diagnosis. The analytical sensitivity (LOD) is the lowest measurable concentration of analyte that gives reliable results; the sensitivity of this assay ranged from 0.021 to 50.104 DNA copies for each pathogen. The within-run, lot-to-lot assay of the kit were stable and excellent.

For combinations of pathogens with a high prevalence of coinfection (NG and CT, HSV-1 and HSV-2), we confirmed that there was no interference in the assay by varying their concentrations. We also evaluated the clinical performance of the $E$ kit in 322 clinical samples. Four discrepancies were observed between the results of the test (E kit) and control (Wise STD 6 kit). However, sequencing confirmed the results of the test kit. Therefore, we confirmed that the $E$ kit has high sensitivity and specificity for 13 pathogens.

Early diagnosis may reduce the complications or sequelae of STIs and reduce the risk of transmission, and thus this multiplex PCR test for STI is expected to be very useful in the clinical field. Although the clinical performance of the kit for HD could not be confirmed because no positive specimens were isolated during the collection period, our future analysis will apply the test to patients with suspected HD infection. In addition, this study used only one commercial kit for comparison. Therefore, additional study is needed to establish the clinical efficacy of $\mathrm{E}$ kit.

\section{CONFLICTS OF INTEREST}

The authors have no conflicts of interest to declare.

\section{ACKNOWLEDGMENTS}

This work was supported by the Basic Science Research Program through the NRF funded by the Ministry of Science, ICT \& Future Planning (NRF-2015M3A9B5030157). We thank the researchers at Catholic University Viral Immunology Lab and Genetree Research Company for helpful discussions and their technical assistance.

\section{REFERENCES}

1) Muralidhar S. Molecular methods in the laboratory diagnosis of sexually transmitted infections. Indian J Sex Transm Dis AIDS 2015;36: 9-17.

2) Black CM. Current methods of laboratory diagnosis of Chlamydia trachomatis infections. Clin Microbio/ Rev 1997; 10:160-84.

3) Cunningham SA, Mandrekar JN, Rosenblatt JE, Patel R. Rapid PCR Detection of Mycoplasma hominis, Ureaplasma urealyticum, and Ureaplasma parvum. Int J Bacterio/2013;2013:168742.

4) Fernández G, Martró E, González V, Saludes V, Bascuñana E, Marcó C, et al. Usefulness of a novel multiplex real-time PCR assay for the diagnosis of sexually-transmitted infections. Enferm Infecc Microbiol Clin 2016:34:471-6. 
5) Liu H, Rodes B, Chen CY, Steiner B. New tests for syphilis: rational design of a PCR method for detection of Treponema pallidum in clinical specimens using unique regions of the DNA polymerase I gene. J Clin Microbiol 2001;39:1941-6.

6) Orle KA, Gates CA, Martin DH, Body BA, Weiss JB. Simultaneous PCR detection of Haemophilus ducreyi, Treponema pallidum, and herpes simplex virus types 1 and 2 from genital ulcers. J Clin Microbio/1996;34:49-54.

7) Sachdev D, Patel AL, Sonkar SC, Kumari I, Saluja D. Diagnosis of Neisseria gonorrhoeae using molecular beacon. Biomed Res Int 2015;2015:597432.

8) Wroblewski JK, Manhart LE, Dickey KA, Hudspeth MK, Totten PA. Comparison of transcription-mediated amplification and PCR assay results for various genital specimen types for detection of Mycoplasma genitalium. J Clin Microbio/2006;44:3306-12.

9) Satpathy G, Mishra AK, Tandon R, Sharma MK, Sharma A, Nayak N, et al. Evaluation of tear samples for Herpes Simplex Virus 1 (HSV) detection in suspected cases of viral keratitis using PCR assay and conventional laboratory diagnostic tools. Br J Ophthalmo/2011:95:415-8.

10) Van Der Pol B, Williams JA, Taylor SN, Cammarata CL, Rivers CA, Body BA, et al. Detection of Trichomonas vaginalis DNA by use of self-obtained vaginal swabs with the BD ProbeTec Qx assay on the BD Viper system. J Clin Microbiol 2014;52:885-9.

11) World Health Organization. Guidelines for the management of sexually transmitted infections. Geneva, Switzerland; World Health Organization, 2003.

12) World Health Organization. Sexually transmitted infections (ST/S). Geneva, Switzerland; World Health Organization, 2013.

13) Jaschek G, Gaydos CA, Welsh LE, Quinn TC. Direct detection of Chlamydia trachomatis in urine specimens from symptomatic and asymptomatic men by using a rapid polymerase chain reaction assay. J Clin Microbiol 1993:31:1209-12.

14) van Der Schee C, van Belkum A, Zwijgers L, van Der Brugge E, O'Neill EL, Luijendijk A, et al. Improved diagnosis of Trichomonas vaginalis infection by PCR using vaginal swabs and urine specimens compared to diagnosis by wet mount microscopy, culture, and fluorescent staining. J Clin Microbio/ 1999;37:4127-30.

15) Burkardt HJ. Standardization and quality control of PCR analyses. Clin Chem Lab Med 2000;38:87-91.

16) Elnifro EM, Ashshi AM, Cooper RJ, Klapper PE. Multiplex PCR: optimization and application in diagnostic virology. Clin Microbiol Rev 2000;13:559-70.

17) Burg JL, Grover CM, Pouletty P, Boothroyd JC. Direct and sensitive detection of a pathogenic protozoan, Toxoplasma gondii, by polymerase chain reaction. J Clin Microbio/ 1989;27:1787-92.

18) Noordhoek GT, Wolters EC, de Jonge ME, van Embden JD. Detection by polymerase chain reaction of Treponema pallidum DNA in cerebrospinal fluid from neurosyphilis patients before and after antibiotic treatment. J Clin Microbiol 1991;29:1976-84. 
19) Scoular A, Gillespie G, Carman WF. Polymerase chain reaction for diagnosis of genital herpes in a genitourinary medicine clinic. Sex Transm Infect 2002;78:21-5.

20) Kim JJ. Cutaneous diseases of the external genitalia. J Korean Med Assoc 2008;51:449-54.

21) Kim SW. Diagnosis and clinical symptoms of sexually transmitted diseases. J Korean Med Assoc 2008;51:875-83.

22) Flahaut M, Sanglard D, Monod M, Bille J, Rossier M. Rapid detection of Candida albicans in clinical samples by DNA amplification of common regions from C. albicans-secreted aspartic proteinase genes. J Clin Microbio/ 1998;36: 395-401.

23) Battle TJ, Golden MR, Suchland KL, Counts JM, Hughes JP, Stamm WE, et al. Evaluation of laboratory testing methods for Chlamydia trachomatis infection in the era of nucleic acid amplification. J Clin Microbio/ 2001;39: 2924-7.

24) Jaton K, Sahli R, Bille J. Development of polymerase chain reaction assays for detection of Listeria monocytogenes in clinical cerebrospinal fluid samples. J Clin Microbio/1992;30:1931-6.

25) Malloy DC, Nauman RK, Paxton H. Detection of Borrelia burgdorferi using the polymerase chain reaction. J Clin Microbiol 1990;28:1089-93. 